\title{
Efforts of Counterfeiting Criminal Acts Passport Identity
}

\author{
Yusep Mulyana \\ Universitas Pasundan, Indonesia \\ Yusep.mulyana@unpas.ac.id \\ ${ }^{*}$ Corresponding Author
}

How to Cite : Mulyana, Y. (2020). Efforts of Counterfeiting Criminal Acts Passport Identity. International Journal for Educational and Vocational Studies, 2 (8), 690-696. DOI: https://doi.org/10.29103/ijevs.v2i8.2761

\section{ARTICLE HISTORY}

Received: 4 July 2020

Revised: 11 July 2020

Accepted: 17 July 2020

KEYWORDS

Countermeasures Identity Counterfeiting;

Passport

\section{ABSTRACT}

Efforts Made to Overcome Counterfeiting Crimes in the Passport Making System is the Imposition of criminal sanctions related to immigration criminal acts can be carried out effectively if the government conducts effective supervision and legal action against individuals, corporations and officials of relevant government agencies involved in activities that lead to the criminal act of immigration by imposing the maximum sanctions both imprisonment and fines, another effort is by the application of biometric technology, different from the previous technology that separates the making of photographs and fingerprints.Biometric technology can narrow the process within minutes connected online with the central office as a storage of biometric data (face and fingerprint) and between immigration offices to prevent the acquisition of multiple passports to the same person because they have multiple identity documents, the passport data is not necessary again sent to Kemkumham, because the data has been centralized online.

This is an open access article under the CC-BY-SA license.

\section{INTRODUCTION}

Indonesia as one of the countries with the largest population in the world and an island territory, with an area consisting mostly of oceans, of course also has a wide variety of cultures and natural resources. If in other countries know 4 seasons, then in Indonesia only know two seasons, namely the rainy season and the dry season.

This condition influences the natural fertility, so that it can lure foreigners to come to Indonesia, to hitchhike, to make a living, not even a few are sedentary, it is inseparable from the struggle of life. Aside from this struggle for life factor, there are still other factors that cause foreigners to immigrate to Indonesia, namely due to political conflict in their country (Sjariful, 2003).

In a territory of the country therein must be inhabited by a number of residents. They consist of citizens, namely people who are part of a population that is an element of the state, who have an unbroken relationship with their homeland, as long as they are not severed or bound by international law, while residents who are not citizens its relationship with the country which it occupies is only as long as the person concerned resides within the territory of that country (Pasha, 2002). Therefore the government regulates the entry and exit of Indonesian citizens and foreign nationals in the Immigration Law. Thus the task of the Directorate General of Immigration as one of the -
Technical Implementation Units of the Department of Justice which turned into the Department of Justice and Human Rights (HAM) has a very important role to regulate foreign traffic between countries and oversee the arrival, presence and activities of foreigners until leaving the territory of the Republic of Indonesia, this is shown to maintain the smooth and implementation of development safeguards. A reality in Indonesia, that there are still many misuse of passports. In dealing with foreign traffic of every country wherever it is located, in order to maintain its integrity and security, conduct surveillance of foreigners by issuing provisions governing the entry and exit of foreigners into the country or regulating foreigners who should reside in the country.

The role of immigration is very influential in regulating these activities, in that activity certainly many are involved and involved. When someone goes and comes from inside and outside the country certainly needs a visa and passport, it is an obligation that must be carried out for people who will travel to and from abroad. In the last few decades, there have been many forgery acts (forgery) on letters and documents relating to passports. In the Criminal Code there is indeed a special Chapter, Chapter XII which criminalizes falsification of letters, but these provisions are still very general in nature. 
At this time the falsified letters and documents can be in the form of electronic documents sent or stored in electronic files of government agencies, institutions, or individuals. Indonesia should have specific criminal provisions relating to falsification of letters or documents by distinguishing the types of letters or falsification documents, which are lex specialists outside the Criminal Code.Perpetrators of forgery of documents in the form of passports may be subject to sanctions in Law No. 6 of 2011 concerning Immigration. Criminal law sanctions have a preventive effect on the occurrence of violations of legal norms. These specific criminal law sanctions can be distinguished (Pasha, 2002).

\section{Primary functions}

Criminal law functions as a means of crime prevention or a means of social control or community control (as a tool for social engineering). Criminal law has a moral dimension in protecting people and people from crime and criminals as well as protecting citizens from the interference of the authorities who use the criminal as an improper means.

\section{Secondary function}

Arrangements regarding social control that are carried out spontaneously or are made by the state with its equipment.

\section{Subsidier function}

Efforts to protect the public from crime should be used by other efforts first. If deemed inadequate, criminal law is used. Efforts to protect the public from crime as an example of crime in the field of immigration. Cut Cynthiara Alona Binti Tengku Umar aka Synthiara Alona has been legally and convincingly proven to have committed a criminal offense "using travel documents of the Republic of Indonesia to enter or exit Indonesian territory, but it is known or reasonably suspected that the Republic of Indonesia travel documents are Fake or falsified", as regulated and threatened with criminal offense in article 126 letter a of RI Law No. 6 of 2011 concerning immigration.

A passport is an official document issued by an authorized official from a country that contains the identity of the holder and is valid for traveling between countries. The passport contains the biodata of the holder, which includes, among others, the holder's photo, signature, place and date of birth, nationality information and sometimes also some other information regarding individual identification. There are also times when a passport includes a list of countries that cannot be entered by the passport holder, but in practice there is falsification of the passport data itself which violates Law No. 6 of 2011 concerning Immigration.

The formulation of the problem in this research is howEfforts to Prevent Criminal Acts of Passport Identity Counterfeiting?.

\section{LITERATURE REVIEW}

\section{Falsification of Letters}

In accordance with the understanding given in the word faux by the makers of the Code Penal, which can be used as objects of faux or forgery only ecrtures or writings only. According to the understanding of the founders of the valid Criminal Code, which can be the object of the crime of forgery of a letter regulated in Chapter XII book II of the Criminal Code. From Article 263 to Article 276 which can be divided into 7 types of falsification of documents, namely:

1. Falsification of Letters in General: the main form of falsification of letters (Article 263).

2. The falsification of the aggravated letter (Article 264).

3. Calling for false information to be entered into the Authentic Deed (Article 266).

4. Falsification of Doctor's Certificate (Articles 267, 266).

5. Falsification of certain documents (Article 267,266).

6. Falsification of Official Certificate of Ownership (Article 274).

7. Storing Materials or Objects for Letter Counterfeiting (275).

8. Article 272 and Article 273 have been revoked through stb. 1926 No.359 jo.429. Article does not contain the formulation of a crime, but on the provision of additional criminal sanctions in the form of the imposition of certain rights under Article 35 No.1-4 for the crime of falsification of letters.

The crime of forgery of letters in general is in the form of forgery of letters in the principal form (standard form) contained in Article 263, which formulates as follows:

"Anyone who makes a fake letter or falsifies a letter that can give rise to rights, commitments or release of debts, or which is intended as evidence of something that is intended to use or order others to use the letter as if the contents are true and not fake, are convicted if Such use can incur losses, due to falsification of the letter, with a maximum imprisonment of 6 years "

Convicted of the same crime, whoever intentionally uses fake or forged letters as if if the use of the letter can cause harm. In Article 263 there are 2 crimes, each formulated in paragraphs 1 and 2 .

The formula in paragraph 1 consists of the following elements:

1 Subjective elements with the intention to use them as original and unauthorized letters or to make others use the person.

2. Objective elements:
a. Whoever;
b. Fabricate or fabricate;
c. A letter that can give rise to a right, an engagement or a debt relief or;
d. A letter that is intended to prove a reality;
e. Its use can cause a loss. 
Paragraph 2 has the following elements:

Objective elements:

Actions: Wearing;

The objects are: a) fake letters; b) falsified letters; The use of the letter can cause losses.

Subjective elements: Purposely

Letter (grechrift) is a sheet of paper on which there is writing consisting of sentences and letters including numbers containing/containing certain thoughts or meanings, which can be written by hand, with typewriters, computer printers, with printed machines and with tools and whatever method. Making a fake letter (making fake / valschelijk opmaaken a letter) is to make a letter that is wholly or part of its contents fake. Fake means that it is not true or contrary to the truth.

\section{Immigration}

Immigration is a matter of the traffic of people entering or outside the territory of the Republic of Indonesia and the supervision of foreigners in the territory of the Republic of Indonesia (Law Number 9 of 1992 concerning Immigration). Whereas the other meaning of Immigration is the matter of the traffic of people entering or leaving the Territory of Indonesia and its supervision in the context of maintaining the upholding of the country's sovereignty (Law Number 6 of 2011 concerning Immigration). In accordance with Republic of Indonesia Law No. 6 of 2011 concerning Immigration The Immigration Function is part of the affairs of the state government in providing Immigration services, law enforcement, state security, and community welfare development facilitators.

Types of Immigration Services:

1 Extension of Kunjugan Stay Permit;

2 Issuance of new Limited Stay Permit Cards (KITAS);

3 Extension of a Limited Stay Permit Card (KITAS);

4 Issuance of Permanent Stay Permit Card (KITAP);

5 Extension of Permanent Stay Permit Card (KITAP);

6 Transfer of Position or Sponsor;

7 7. Transfer of Status of Stay Permit;

8 Job status addition (multiple positions);

9 Immigration Certificate for citizenship application (Naturalization);

10 Returning Documents/Revocation of Foreign Citizen status because they have obtained Indonesian Citizenship;

11 11. Re-entry Permit (MERP/ERP);

12 Permit to Leave Indonesia to not return (EPO);

13 Reports on Births, marriages, deaths, and leaving the territory of the Republic of Indonesia do not return;

14 Registration to get a Dual Citizenship Immigration Facility (Affidavit)

\section{Passport and Passport Counterfeiting Criminal Acts}

Passport is document official issued by an authorized official of an country which loads identity holders and applies for travel between countries.

Passport contains biodata its holders, which include, among others, photo holder, signature, place and date of birth, nationality information and sometimes some other information regarding individual identification. There are also times when a passport includes a list of countries that the passport holder cannot enter. For example, in the past Indonesian passport holders were banned from visiting the countryIsrael and Taiwanese.

At present several countries have issued what is called e-passportor electronic passport. e-passport is the development of the current conventional passport where a passport has been implantedthe chip which contains the holder's biodata along with data biometricsof this biometric data is stored with the intention of making sure that the person holding the passport is the true person who owns and has the right to the passport.

A passport is usually required for international travel because it must be presented when entering a country's border, although in certain countries there are several agreements where citizens of a certain country can enter another country with documents other than a passport. Passports will be stamped (stamp) or sealed with Visa conducted by the official of the country of arrival.

Some governments try to control the movements of their citizens and foreigners in their countries by issuing "internal passports". For example in a former countrySoviet Union, for each citizen a "propiska"to control their movements in all regions of the country. This system is still partially implemented in Russia.

\section{Passport Types (Passport, 2020):}

\section{Ordinary passport}

Usually a country issues to its citizens an ordinary passport for regular travel. In Indonesia this passport is given a green cover and is issued by the Directorate General of Immigration, the Ministry of Law and Human Rights.

\section{Diplomatic passport}

For some people diplomatic passports are issued to identify them as diplomatic representatives from their home countries. Because of this, passport holders enjoy some ease of treatment and immunity in their host country. In Indonesia, this passport is given a black cover and is issued by the Ministry of Foreign Affairs.

\section{Official/official passport}

This passport was issued to the technicians and administrative officers of a mission diplomatic as Embassy and consulate or for government employees/ government that is carrying out overseas assignments. This type of passport holders get some facilities that are not owned by ordinary passport holders. In Indonesia, this passport is given a blue cover and is issued by the Ministry of Foreign Affairs after obtaining permission from the State Secretariat.

\section{Foreign passport}

A foreign passport is a passport given to someone who is not a citizen. The terms and conditions for having this type of passport are regulated by each country. Examples of these passports are passports used for hajj (brown passports), which are issued by the Government of the 
Kingdom of Saudi Arabia.

\section{Group passport}

A group passport will be given for, for example, a school trip children's vacation group. All children on the trip have enough to have a group passport during their vacation trip.

\section{Hajj and Umrah passports}

Especially for pilgrims and umrah, the name listed in the passport must use 3 words such as "Ahmad Hasan Ismail"

The practice of implementing immigration law, of course not all problems in the field of immigration can run in accordance with immigration regulations, there are many violations, crimes and irregularities in the field of immigration. The development of technology and the structure of the international community has relevance for the emergence of transnational crime forms, including organizations as a forum. This form of crime is better known as transnational crime, which in fact has a structure or organizer, so it is known as transnational organized crime, such as corruption, money laundering, smuggling of people (smuggling of migrants) (Bassiouni, 2009). Therefore there is a need for cooperation between countries both bilateral and multilateral to prevent, eradicate, combat transnational and organized crime.

The crime of falsifying immigration documents, namely passports, is a criminal offense that harms the state. Investigation action up to the decision on the application of criminal sanctions is a series of results of immigration control activities. To safeguard and ensure that all people entering and leaving a country comply with all immigration requirements. Every immigration administration must conduct surveillance activities. Immigration control activities must cover all the exercise of authority held by immigration officers in their legislation, namely checking, passengers, documents, accounting, confiscation, arrest, and others.

The rise of the phenomenon of crime in the immigration environment, especially the falsification of immigration supplementary documents, namely passports and/or providing information either verbally or written falsely or falsified in the area of immigration law requires the presence of a special unit tasked with investigating and investigating this case. The Directorate General of Immigration should establish a special unit to handle customs crime cases that are responsible for law enforcement tasks relating to immigration criminal acts. The crime of falsifying immigration documents, namely passports, is a criminal offense that harms the state.

\section{Forms and Sanctions for Immigration Crimes}

Misuse of immigration documents is regulated in Chapter VIII of Law Number 9 of 1992 as amended by Law No. 6 of 2011 concerning Immigration regarding criminal provisions that can be applied if doing the following:

a. Foreigners who deliberately fake or falsify a Visa or immigration permit.

b. Foreigners who deliberately use fake or fake immigration permits or falsified to enter or be in
Indonesian territory.

c. Foreigners who intentionally misuse or carry out activities that are not in accordance with the purpose of granting immigration permits granted to them.

d. Any person who intentionally: (a) uses a Republic of Indonesia Travel Document while knowing or duly suspected that a Travel Document is fake or falsified, (b) uses another person's Travel Letter or Republic of Indonesia Travel Letter that has been revoked or declared canceled, or surrenders to others Republic of Indonesia Travel Letters given to him, with the intention of being used unauthorizedly. (c) providing invalid data or incorrect information to obtain a Republic of Indonesia Travel Document for himself or someone else, (d) possessing or using unlawfully 2 (two) or more Republic of Indonesia Travel Documents, all of which are valid.

e. Any person who intentionally and unlawfully prints, has, kept a blank Travel Document of the Republic of Indonesia or a blank immigration document.

f. Any person who intentionally and unlawfully creates, owns or keeps a stamp that is used to ratify a Republic of Indonesia Travel Document or immigration document.

g. Any person who intentionally and unlawfully for the benefit of himself or another person damages, removes or changes either part or all of the information or stamp contained in the Republic of Indonesia Travel Letter;

h. Any person who intentionally and unlawfully for the benefit of himself or someone else owns, stores, changes or uses immigration data both manually and electronically.

i. Officials who intentionally and unlawfully provide or extend the validity of a Republic of Indonesia Travel Document or immigration document to someone they know has no right.

\section{Passport Making Process}

Republic of Indonesia Travel Document (SPRI / Passport) is a state-owned document that must be protected and maintained. The SPRI holder is fully responsible for his SPRI. The passport is valid for 5 (five) years from the date of issue. RI passports (SPRI) that need to be replaced are (Passpot, 2020):

1. A passport whose validity period has reached five years from the date of issue.

2. Passport that runs out of pages.

3. Lost passport with information from the local police and a photocopy of the passport.

Procedures and requirements that must be met (Indonesian Embassy, 2020):

1. The making of a new RI passport cannot be represented to others or by post, but must be done by the owner/holder of the RI passport itself and come directly to the Consular Section of the Indonesian Embassy in London by bringing the old Passport (SPRI). 
2. For lost passports, the applicant must bring a certificate of reporting a lost passport from the local police.

3. Applicants can come directly to the Indonesian Consulate in London on every working day (except on Indonesian and English holidays) between 10:00-13:00 (Monday-Thursday) and 10:00-12.00 (Friday) for document submission and 14.30 - 16.00 for document collection.

4. Complete the RI Immigration Form (Perdim 14) in full with printed letters, affixed the applicant's last photo, affixed with the right thumbprint on the column provided and signed by the applicant himself. The signatures must match those stated in the passport, and may not be in the name or be represented by someone else.

5. Fill in the Consular Field Form completely, honestly and signed by the applicant in accordance with what is stated in the passport.

6. Attach passports as many as 4 (four) passport-size sheets, with a Red Background (in accordance with RI Travel Document Regulations).

7. Making a new SPRI can be done as soon as 6 (six) months before the expiration date.

8. The process of making a New RI Passport takes 1 (one) working day, except in certain circumstances, the process of making a new passport can take longer.

9. Cost of making a Passport (SPRI):

a. Cost of making a new passport: $£ 20.00$ per passport (one person).

b. As for fines for lost or late passports: $£ 20.00$ per person

c. Payment is only in the form of a Postal Order or bank draft only to Indonesian Embassy or made by debit card at the time of collection.

10. For those who want a passport return (SPRI) through the postal service, to be delivered to the Indonesian Embassy in London, one SPECIAL DELIVERY envelope with a complete return address (including the POS CODE).

11. If there is damage /loss /delay during the process of sending the passport by post it is not the responsibility of the Indonesian ConsularAffairs Consulate in London.

If the passport is lost, immediately report the loss to the local police. After obtaining a statement of loss reporting from the police, bring the letter to the Indonesian Representative to make a new passport or Passport-Like Travel Letter (SPLP) (Passport, 2020).

Steps to register for a passport online (Passport, 2020):

1 Prepare all the required documents starting from a valid KTP, family card, marriage certificate, birth certificate, and diploma.

2 Scanthe documents are in black and white image format (Jpeg). All scans must not exceed $300 \mathrm{~kb}$ in size.

3 Open sitewww.imigration.go.idthen select the menu Public Service - Online Service - Online Passport

\section{Service.}

4 Select the type of passport to be made, then fill in the requested personal data completely and correctly.

5 The next page is still in the form of personal data. This time, the requested data is personal data of father, mother, and husband or child. Also fill the page completely and correctly then choose advanced options.

6 Upload results a scandocuments that you have created in the space provided. Please remember that the document must be black and white and its size does not exceed $300 \mathrm{~kb}$. If not, upload /uploaded could fail.

7 Choose a location to take care of your passport and date of arrival. This choice will determine where and when you will proceed with the passport management process, which includes submission of files, payments, fingerprints, photographs, interviews, payments, and retrieval of ready-made passports.

8 Enter the verification code that appears on the computer screen, then select OK. Next, a notification will appear that you have pre-applied for your passport. You must also print a Pre-Passport Request Receipt that is available.

\section{Counterfeiting Criminal Acts in the Passport Making System}

The importance of effective law enforcement against criminal acts in Indonesia is one of the pillars of the realization of the development of law in the conduct of community and national life in accordance with the characteristics in each rule of law. It is the duty of all citizens to create harmony and balance in their lives where their rights and obligations can be fully implemented.

The imposition of criminal sanctions against immigration offenders is aimed at enforcing immigration provisions as well as trying to prevent and eradicate illegal acts that can harm the state and society. Imposition of imprisonment sanctions and fines currently in force have not been able to be comprehensive, effective and provide a deterrent effect for perpetrators and others not to imitate the same act to suppress immigration crimes. It is necessary to improve the aspects of immigration supervision and enforcement of activities that lead to acts that violate immigration laws. The forms of criminal acts of immigration can be done by individuals or corporations for the benefit of themselves or others intentionally and against the law. The imposition of criminal sanctions against immigration offenders is aimed at enforcing immigration provisions as well as trying to prevent and eradicate illegal acts that can harm the state and society.

Imposition of imprisonment sanctions and fines currently in force have not been able to be comprehensive, effective and provide a deterrent effect for perpetrators and others not to imitate the same act to suppress immigration crimes. This is also caused by the involvement of government officials since the 
management of one's identity as a condition for obtaining immigration documents.

Enforcement of criminal sanctions related to immigration offenses can run effectively if the government carries out effective supervision and legal action against individuals, corporations and officials of relevant government agencies involved in activities that lead to immigration crime by imposing the maximum sanctions both imprisonment and fines in accordance with the evidence and confidence of the panel of judges in the trial and based on the losses that have been experienced by the state and community members due to the immigration crime.

The handling of crimes by immigration officials is only in the form of deportation, there is no pro justification process, with the reason that there are no articles that regulate the Immigration Act and are concerned about the involvement of immigration officials when using the counterfeiting article in the Criminal Code. The crimes are transnational crimes, so cooperation between countries is needed to combat these crimes, one of which is Mutual Legal Assistance (MLA), which is contained in the TOC Convention. Law enforcement against foreign passport forgery has not been effective as intended, because the perpetrators are only subject to expulsion, so there is no deterrent effect resulting in the offender coming back with a different modus operandi.

In fact, the new version of the travel document is the same as the current passport, but it is equipped with a chip or computer chip containing passport holder data. So there is a visual that can be seen with the eye, typed normally or data and images that can be seen.

In addition there is data stored in the form of chips so that if visual data is held changes, what is on that chip cannot be changed. Even if typed and pasted the photo but, because it does not go through the system in its processing will not be read in the chip. Since 2015 all passports in Indonesia have used this technology.

In the end, technology is only a tool, but the one who decides is the person behind it. On the other hand, e-passports are clearly a step forward towards better conditions and reduce opportunities for fraud. This model might actually have to be extended to other things, such as KTP or SIM, to guarantee a better and cleaner process than possible forgery.

An electronic passport, also known as e-passport, was launched on January 26, 2011, to coincide with the Immigration 61st Anniversary event. The launch of e-passports also marked a new era in handling passports in Indonesia. Electronic passports are reliable in overcoming various passport counterfeiting acts, so there are no more fake passport cases such as the Gayus Halomoan Tambunan passport case. Besides being safe, the use of an electronic passport is also more practical, because the owner no longer needs to carry a passport in book form.

That e-passports cannot be falsified. The launching of e-passports is an effort to monitor and improve the security of immigration documents that were previously vulnerable to forgery, such as the case of the Gayaf Tambunan tax mafia convicted passport. Electronic passports are equipped with chips that hold the passport holder data, making it difficult to fake.

Indeed, a number of countries have used e-passports, including Malaysia, the United States, Australia, Britain, Japan, New Zealand, Sweden, and other countries. Biometric data stored on e-passport chips varies between countries, but based on standards issued by the International Civil Aviation Organization (ICAO), the biometric data used is biometric data from the face of the passport holder with biometric fingerprints as its backers.

But until now the standardization issued by ICAO has not been agreed upon by the international community for various reasons. Currently Indonesia has used the biometric data of the passport applicant as one of the security elements in the issuance of the passport of the Republic of Indonesia. The use of e-passports is a follow up to the implementation of the immigration management information system (SIMKIM) at the Directorate General of Immigration. E-passports refer to international standards issued by ICAO in the issuance of electronic passports and biometric data specifications.

E-passports keep up with world developments, especially in terms of issuing safer and more reliable travel documents and to align Indonesia with other countries in the world, and more importantly to improve the quality of public services.

Based on the provisions of the ICAO-9303 document, a number of elements that are e-passport requirements are: Machine Readable Zone (MRZ) and passport data pages according to ICAO standards, passport holders can only have 1 (one) valid similar passport, stored data the chip must be the same as the data printed on the passport data page, the data security system (Key Management System-KMS) and biometric facial data (Mandatory), fingerprint (Optional).

In accordance with the ICAO recommendation, the data contained in the passport biodata page includes: passport unique number, unique national identity number, passport holder's full name, country code, color photo, passport holder's signature, passport holder nationality, passport issuance date, passport expiry date, date of birth of passport holder, place of birth of passport holder, sex of passport holder, place of passport issued, 2 lines of Machine Readable Zone (MRZ).

\section{RESEARCH METHODS}

This type of research is descriptive, so this research is expected to explain the phenomena that exist, especially those related toEfforts to Prevent Criminal Acts of Passport Identity Counterfeiting.

\section{CONCLUSION}

Efforts Made to Overcome Counterfeiting Criminal Acts in the Passport Making System is the Imposition of 
criminal sanctions related to immigration criminal acts can be carried out effectively if the government carries out effective supervision and legal action against individuals, corporations and officials of relevant government agencies involved in activities that lead to the criminal act of immigration by imposing the maximum sanctions both imprisonment and fines, another effort is by the application of biometric technology, different from the previous technology that separates the making of photographs and fingerprints.Biometric technology can narrow the process within minutes connected online with the central office as a storage of biometric data (face and fingerprint) and between immigration offices to prevent the acquisition of multiple passports to the same person because they have multiple identity documents, the passport data is not necessary again sent to Kemkumham, because the data has been centralized online.

- Counterfeiting Crimes in the Passport Making System Using the Use of the Identity of Other Persons is guided by Article 126 letter a of RI Law No. 6 of 2001 concerning Immigration, the elements of which are as follows for every person, intentionally using travel documents of the Republic of Indonesia to enter or exit Indonesian territory, but it is known or reasonably suspected that the travel documents of the Republic of Indonesia are fake or falsified.

\section{SUGGESTION}

1. The use of information and electronic technology in handling passport counterfeiting crimes needs to be accompanied by quality human resources.

2. The criminal act of forgery of passports involving inter-countries needs to be handled extraordinarily.

\section{REFERENCES}

Andi, Hamzah. (2005). Principles of Criminal Law, Yasrif Watampone, Jakarta.

Achmad, Ali. (2006). Revealing the Veil of Law, (A Philosophical and Sociological Study,) Chandra Pratama, Jakarta.

Barda, Nawawi Arief. (2008). Bunga Rampai Criminal Law Policy Development of the Drafting of the New Criminal Code Concept, Prenada Media Group, Jakarta.

Bassiouni, M. (2009). Cherif, "International Criminal Law, Volume I: Crimes, Transnational Publicists Inc.", Dobb Ferry, New York.

EY Kanter and SR Sianturi. (2006). Principles of Criminal Law in Indonesia and Their Application, AHM-PTHM Alumni, Jakarta.

Fischer, Robert J and Gion Green. (2008). Introduction to security, Elsevier Science USA, Butterworth Heinemann, sixth Ed.

Gerhard OW Mueller. (2008). Transnational Crime: Definitions and Concepts, Transnational Organized Crime, No. 4 of 2008
JM Van Bemmelen, (2009). Ons Strafrecht 1: Het Materiele Strafrecht Algemen dell, HD Tjeenk Willink, Alphen aan den Rijn, Holland.

http://en.wikipedia.org/wiki/Paspor, downloaded on February 21, 2020

http://www.indonesianembassy.org.uk/

consular /consular_wni_baru_passport.html

http://www.voucherhotel.com/travel guide-making-passport-online/accessed June 16, 2020

Lilik, Mulyadi. (2007). Reversal of Corruption Proof Burden, Alumni, Bandung.

Martin, JM and Romano, AT. (2002). Multinational Crime-Terrorism, Espionage, Drug \& Arms Trafficking, SAGE Publications, 2002.

Muhammad Ekaputra and Abdul Kahir. (2010). Criminal System in the Criminal Code and Its Arrangement According to the New Criminal Code Concept. Medan: Usu Press.

Muladi. (2005). Conditional Criminal Institution, Alumni, Bandung.

Moeljatno. (2002). Principles of Criminal Law, cet. 7, PT. Rineka Cipta. Jakarta. 2002.

PAF Lamintang. (2000). Fundamentals of Criminal Law in Indonesia, Sinar Baru Bandung.

O'block L, Robert. (2001). Security and crime prevention, CV Mosby Company, St. Louis.

Oka A. Yoeti. (2005). Tours and Travel Management, Fourth Printing, Pradnya Paramita, Jakarta.

Pasha, M., K., (2002). Citizenship Education, Citra Karsa Mandiri, Yogyakarta.

RM, Suharto. (2002). Criminal Law Subjective Objective Elements as a Basis for Indictment, Sinar Grafika, Jakarta. 2002.

Romli Atmasasmita. (2007). Transnational Narcotics Narcotics in the Indonesian Criminal Law System. Citra Aditya Bakti. Bandung.

Roeslan Saleh. (2007). Some Notes about Acts and Errors in Criminal Law, Rineka Cipta, Bandung.

Sjahriful, A., (2003). Introducing Immigration Law, First Printing, GhaliaIndonesia, Jakarta.

Sudarto. (2003). Criminal Law and Community Development (Study of Criminal Law Reform), Sinar Baru, Bandung.

SR Sianturi. (2009). Principles of Criminal Law in Indonesia and the Implementation of Alumni Ahaem-Petehaem, Jakarta.

Usman Simanjuntak. (2004). Prosecution and Legal Efforts, Bina Cipta, Jakarta.

Law Number 9 of 1992 concerning Immigration

Law Number 6 of 2011 concerning Immigration. 